\title{
Gestures in Kathakali: a Study on Protagonist and Antagonist Performances in Stories
}

\author{
Vishnu Achutha Menon ${ }^{1} \&$ Boobalikrishnan $\mathrm{N}^{2}$ \\ ${ }^{1}$ Ph.D. scholar, Department of Media and Communication, Central University of Tamil \\ Nadu. ORCID: oooo-0o03-4028-3685. Email:vishnuamenon@gmail.com \\ ${ }^{2}$ Faculty at the department of media and communication, Central University of Tamil Nadu.
}

\begin{abstract}
Kathakali is the indigenous art form of Kerala, the southern state of India. Katha means Story and Kali means Performance. The stories are taken from mythology in which, legendry characters are brought to live through performances. The characters are categorized as Protagonist (Key characters) and Antagonist (Anti-hero characters). This study aims to understand how different forms of non-verbal communication are used as a tool for communicating through all performing characters. The focus of study will be on Protagonist and Antagonist.
\end{abstract}

Keywords: Kathakali, Non- Verbal Communication, Kerala.

\section{Introduction}

Kathakali, the world renowned Classical Dance-Drama of Kerala, originated in Kottarakkara during the first quarter of the 15th Century. It was then known as RAMANATTAM. This art form slowly made its impact throughout Kerala, with the introduction of four classical stories with human heroes by Kottayath Thampuran (North) in the second half of the 17th Century, Ramanattam started known as KATHAKALI. Thus, this art form left its divine nature and transformed into an absolute theatre status by the 18th century. The unique style of depiction of the Bhavas (Emotional states), physical movements, the interfiling dance-element and colorful costumes were widely acclaimed. By 1950 s this classical art form attracted connoisseurs from all over the world.

Kathakali is the total theatre of Kerala. The term Kathakali is derived from two words Katha means the story and Kali means play, in which actors delineate the stories to conceal their identity in magnificent colours. The characters of this theater are grouped on the basis of three gunas (quality). Satwa, Rajas and Thamas. Righteous gentle and soft characters are known as Minukku, royal righteous ones are Pacha, more dignified warriors with little aggressive nature are Kathi more aggressive ones are Thadi primitive characters are kari. Taxonomy of characters is based on the colors of the face, costumes, and patterns drawn on the face and the crowns and the cloths. A character in a play is assigned to one of these roles depending upon the Sthayibhava (a predominant emotional status) and mood attributed on the particular occasion of the play.

Kathakali is pantomime super. The characters never speak. The transfer of emotional state and dialogues to audiences is achieved by processes like Kinesics, Oculesics, Grunts, Gait,

(C) AesthetixMS 2018. This Open Access article is published under a Creative Commons Attribution Non-Commercial 4.0 International License (http://creativecommons.org/licenses/by-nc/4.0/), which permits non-commercial re-use, distribution, and reproduction in any medium, provided the original work is properly cited. For citation use the DOI. For commercial re-use, please contact editor@chitrolekha.com 
Postures and Gestures, Haptics and Costumes. This study tries to explore the non-verbal communication process and criteria of attribution of character's role in Kathakali play with a comparison of Protagonists and Antagonists roles.

All realms Non-Verbal communication is best explored in the process of enacting of Kathakali. In Kathakali performers bring action for all spoken words by the singers, and no words are wasted. This study aims to understand how non-verbal communication is effectively used in Kathakali, non - verbal forms include Kinesics, Gait, Haptics, Postures and Gestures, Grunts and Oculesics. The researchers chose observation study for their research. Some of the the prominent plays were observed for the same. The plays are Seethaswayamvaram, Baalivadham, Bakavadham, Kalyana Saugandhikam, Kaalakeyavadham, Kiratham, Baalivijayam, Keechakavadham, Dakhayagam, Rajasooyam, Narakasuravadham and Baanayudham.

\section{Kathakali and Natyashastra}

[Whether Kathakali really making use of non-verbal communication how signs and symbols contributes meaning. In this study the researcher may apply Ferdinand De Saussure's (1857-1913) semiotics theory to check the effective usage of non-verbal communication in Kathakali and "How signs and symbols contributes meaning".]

The theory of enacting process of Kathakali is based on Sage Bharatha's Natyashastra. According to Natyashastra, Abhinaya (the process of enacting) has four components, viz. Sathvik, Angik, Vachik and Aharya, which are otherwise different stages of evolution of emotion in living beings. Abhinaya is the process of carrying one's mind (Naya) by another in direct presence (Abhi).

\section{Chadurvidhabhinaya the Four stages of enacting- or the Process of Emotion originating in Subtle Sub-conscious Mind and getting expressed as Oculesics, Kinesics, Gait, Postures and Gestures}

The four stages of evolution process of Abhinaya can be visualized as follows. The emotion depicted originates in the Mind due to a situation or object called the Alambhana Vibhava (original Cause). This emotion grows by other complimenting elements, called Udheepana Vibhavas. When fully matured with time, this emotion brims in Mind and involuntarily gets exhibited in the Body, especially on face. Such a response of the Eyes and Facial Muscles in the emotional state is known as the Sthayibhava. This process as a whole is known as Sathvik Abhinaya. The state of emotion, called Bhava, spreads to limbs Hands, Legs and the Body and leads to subsequent movements in accordance with emotion is called Angik Abhinaya. Now the person starts venting out his emotion by verbal expression, which is Vachik Abhinaya. The dress or costume which enhances the physical appearance of the actor is the Aharya Abhinaya. In these four, except the Vachik Abhinaya all other three stages are purely Non-Verbal.

\section{Bhavas and Rasas- The Communication Process}

All the emotional states of a person are classified into eight categories viz. Eight Sthayi Bhavas. When all the Sthayi Bhavas are remaining in equilibrium, the state is the ninth Bhava, Nirvedam. When the actor depicts these Sthayibhavas, the connoisseur's mind responds and gets tuned to 
the situation. In such tuned state, the Bhava from actor gets communicated and what the receptor feels is the corresponding Rasa. Hence, corresponding to the Nine Sthayibhava of the actor, the receptor stimulates corresponding Rasas. The Sthayi Bhavas and corresponding Rasas are as follows.

Rathi - Shrungara, Haasam - Haasyam, Shokam -Karunam, Krodham - Raudram, Utsaham- Veeram, Bhayam - Bhayanakam, Jugupsa - Bhebalsam, Vismayam - Atbhutham \& Nirvedam - Samtham

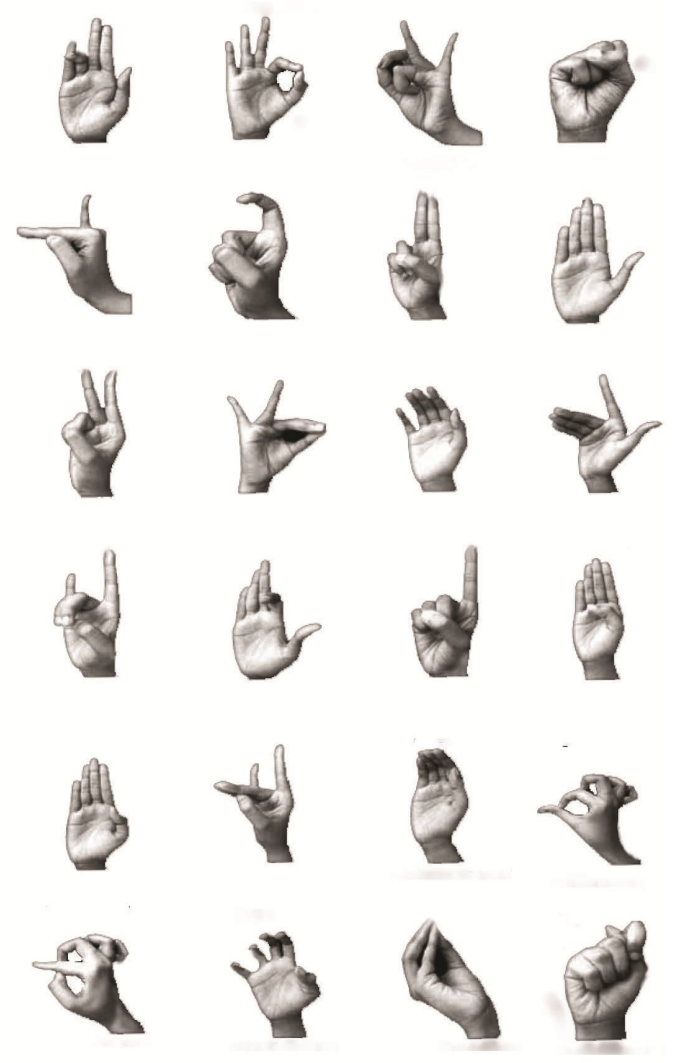

Figure 1 : Basic Mudras

\section{Unique features of Non-Verbal Communication in Kathakali}

In Kathakali the actors do not speak. Two playback singers render verses of Attakatha (Lines of Kathakali Text). The main content of the text are dialogues of characters. It also includes lines stating the situation, emotional state of character and other aspects. The whole sequence of enacting of characters fall into two parts, viz. the acting of the verses sung - Cholliyattam, and acting in accordance with drums without background rendering of verses, the Elakiyattam.

\section{1] Oculesics in Sathika Abhinaya}

It is said that where there is Mudra the Mind is there and the eyes are naturally there. The eyes focus where the mind does. As mentioned, the prime media of expression of Bhava in Sathvik 
Abhinaya are eyes. This is achieved by Kannusadhaka- regular and delicate training in movement of eyeballs and eye-bros. Early morning 3.30 AM is considered as the time to start eye exercises. Students, after applying pure Ghee in eyes, keeping open the eyes by holding the lids by fingers, does an hour dynamic movements of eye balls such as cross, diagonal, figure eight etc with applying mental strength to eyeballs (Vayukodukkal).

\section{2] Kinesics, Gait, Postures and Gestures}

Cholliyattam: Cholliyattam is based on enacting Verbatim or Padarthabhinaya. The whole text sung by the singer is enacted word by word. Such a process, in addition to acting verbatim, should also have the embedded Sthayi Bhava of the character, Sancharibhava -the overlapping alternating mood, and the message of the situation. This sophisticated blending can only be achieved by a powerful expressive body language with effective Kinesics, Gait, Postures, and Gestures and by a delicate depiction of emotional state with appropriate Oculesics complimented by Grunts.

The Body Language of the actor has 24 basic Alphabets viz. the basic MUDRAS. These are a sequence of movements of the limbs of the body with a starting posture, sequence of movements ending in a defined posture with emphasis on position of palm and fingers. The word or noun is conveyed mainly by the hands or fingers and so these are also called HASTHA MUDRAS (Signs of Hands). The Kathakali Mudras are based on Hasthalakshanadeepika (author unknown). The position of hands with Mudras, variation of Mudras in hands etc. has different attributed meanings. An actor can depict word, sentences and a full situation by combination of Mudras.

During Cholliyattam, the singers repeat the verses until the actor finishes his dialogue verbatim once.

Elakiyattam: Elakiyattam is the pinnacle situation of Non-Verbal Communication in Kathakali. During Elakiyattam there is no singing. The actor presents the whole situation by his silent language by effective and apt usage of Kinesics, Gait, Postures, Gestures and Oculesics complimented by Grunts. The enacting sequence may run to a time span hours. Here the actor has freedom to deviate from the main stream and can enact Flashbacks, History, SelfAchievements, Wars, Scenes of Natural Beauty etc. This is the occasion when the actor brings his innovative talents to stage. An educated connoisseur yearns for such performances. A predefined Elakiyattam sequence is considered as the uniqueness or CHITTA of a story and is judged as the grade of classism.

\section{3] Grunts}

Character types other than Pacha and Minukku never make any sound. The Kathi, Thaadi and Kari characters utter their characteristic sounds (Hanuman- like a Monkey etc.).

Similarities and differences of non-verbal communication adopted by Protagonists and Antagonists: In Kathakali, protagonists resemble Shakespeare's heroes. Protagonists of popular stories are 'exceptional calamities occurring to the distinguished personalities of highest state and rank' (Dr Johonson). 
84 Gestures in Kathakali: a Study on Protagonist and Antagonist Performances in Stories

\section{Role and Appearance of Characters}

Characters are divided into types. Pacha- the righteous royal, Kathi- the self-made partly villainous, Thaadi- the vigorous and dynamic, Kari- the primitive and Minukku- the sober. These types are well marked by their appearance as have varied costumes. Pachas and Kathis assume Protagonist roles in most of the stories. Thaadi- especially Chuvanna Thadis mostly oppose the heroes, assume Antagonist role and meet with death. The appearance of Protagonist roles Pacha and Kathi are very similar nature. They have similar costumes and headgears. However, the facial makeup vary. Pacha has predominant Green colour while Kathi has a knife-like red mark drawn by the sides of nose and have a ball like projection on nose and forehead.

The Antagonists Chuvanna Thaadi and Kari have huge head gears and are fearsome in appearance. They have elaborate decorations on their breast. Chuvanna Thaadi has a big Red beard around its chin, while Kari (male) has a Black one. Kari (female) has huge protruding breasts. All of them have big incisor teeth which they exhibit during war or encounters with enemies. In other words they "show their teeth" in time.

\section{1] Kinesics, Gait, Postures and Gestures and Tempo}

Though the meaning of Mudra and Nrutha i.e. the Kinesics, Gait, Postures and Gestures are similar, the Protagonists perform it in a sober phase. The first introduction of Kathi is through a sophisticated prelude scene called Thiranokku, often followed by a Thandedattam, wherein the flashback of his achievements is enacted without the support of singing. The whole sequence is purely non-verbal. Pachas have a Kitathakitam, a graceful sequence of entering into the scene, in the slowest tempo. Throughout the enacting these roles resort to slow tempo.

Thaadis, the antagonists, also have the prelude Thiranokku and Thandedattam, but in high tempo of rhythms, often with the accompaniment of many drums to create a fearsome dynamic atmosphere. These are vigorous characters, wearing weapons, always moving in highly increased speed. They are not as meticulous in hand gestures as Protagonists.

The Kinesics of characters has two aspects, the way of body movements and the tempo of execution. A particular specified sequence of Kinesics is called Kalaasa. The Kalaasa are of many types, based on varied Thaala (specific combination of basic beats) and varied styles. The style of performance of such Kalaasams of Protagonists and Antagonists vary. Though all Kalasams are executed by all actors, a very general classification can be as follows.

\section{2] Grunts}

The only sounds that characters utter are the occasional Grunts. The characters of Pacha, Minukku never make any sound. The Kathi, Thaadi and Kari characters utter their characteristic sounds (Hanuman- like a Monkey etc.). These grunts delivered at specific occasion's compliments their present Bhava and should be in tune with the Shruthi, the frequency multiples of Singers and in unison with the tempo.

From Table I it can be generally stated that Pacha and Chuvanna Thaadi types of characters can be taken for a typical study of comparison of Protagonist and Antagonist roles in 
Kathakali. Characters from four stories Baalivadham, Bakavadham, Dakshayagam and Nalacharithm (Please see Table IV below) are selected for this study.

\section{Baalivadham}

In this story, wherein parts of Ramayana are depicted, Sreerama is the sober Protagonist. He is Pacha type. The Kinesics -movements are in slow tempo Rhythms some parts as slow as in 32 basic beats. The Antagonist Baali is Chuvanna Thaadi, ferocious and has vigorous Kinesics in fast tempo Muriyadantha.

The facial makeup of Sreerama is Green predominant with small headgear. The postures and gestures are mostly Welcoming- folded palms or open hands, Blessing- open Right arm, Solacing- bent shoulders and. absolutely silent with no grunts. While Baali's postures and gestures Commanding- upright, Proud- bent backwards, Arrogant and Demanding- Calling for fight, wearing arms in hand with shouting and uttering loud. The appearance is ferocious with curved lines in Red background on face, Red beard around chin with biggest headgear Kuttichamaram.

\section{Bakavadham}

In this part of Mahabharata, Bheema the mighty Protagonist. Puts an end to the atrocities of Baka Rakshasa. Bheema is Pacha type and Baka is Chuvanna Thaadi. The Kinesics -movements of Bheema are in slow tempo during peaceful period which later resorts to faster sequences Champa during encounter with Baka. The Antagonist Baka is ferocious and have vogorous Kinesics in fastest tempo Muriyadantha.

The facial makeup of Bheema is Green predominant with Kesabharam headgear. The postures and gestures are mostly Dignified- upright, Royale- hands drawn and in level with chest, and Affirmative- confident widened legs and arms. Absolutely silent with no grunts. While Baka's postures and gestures are Arrogant, Aggressive and Demanding- Calling for fight, with shouting and uttering loud. The appearance is ferocious with Red background on face, Red beard around chin with biggest headgear.

\section{Dakshayagam}

Story is based on Mahabhagavatha. Daksha the mighty Prajapathi is the Protagonist. He is being killed by Veerabhadra, an orderly of Lord Shiva. Daksha is a Pacha hero and Veerabhadra is Chuvanna Thaadi. The Kinesics -movements of Daksha are in slow tempo during the first part of the story. The Antagonist Veerabhadra is a ferocious demon in Chuvanna Thaadi and has frightening Kinesics in fastest tempo with the accompaniments of Bhadrakaali and Kinkaras.

The facial makeup of Daksha is peaceful Green predominant with Kesabharam headgear. The postures and gestures are mostly Dignified- upright, Royale- hands drawn and in level with chest, and Affirmative- confident with Bows held back. Absolutely silent with no grunts. While Veerabhadra's postures and guessers are very Aggressive, Furious and Demanding- Calling for fight, with shouting and uttering aloud. The appearance is highly dramatized with Red background on face, Red beard around chin, biggest headgear and a big axe in hand. 
86 Gestures in Kathakali: a Study on Protagonist and Antagonist Performances in Stories

\section{Nalacharithm}

Story is based on Mahabharatha. Nala, the righteous King of Naishada is a classic Protagonist belonging to Dheera Saantha of high values. He is being cheated by Kali, a symbolic character of evil fury. Nala is a Pacha hero and Kali belong to a special version of Chuvanna Thaadi. The Kinesics -movements of Nala are extremely graceful an in slow tempo. The Antagonist Kali is a tricky diplomat character. It is marked by tactful Kinesics first in medium and later in fastest tempo of action.

The facial makeup of Nala is Green predominant with Kesabharam headgear. The postures and gestures are mostly Loving- Dignified- upright, Romantic- embracing and Determinedconfident. No grunts. While Kali's postures and guessers are very cunning and demandingCalling for dice game, Lamenting, with shouting and uttering when winning. The appearance is highly dramatized with Red background on face, Black beard around chin with biggest headgear and companionship of a curious friend Dwapara.

Table I Character Type classification of Protagonists and Antagonists in Kathakali Stories

\begin{tabular}{|l|l|l|l|l|}
\hline Story & Protagonist & $\begin{array}{l}\text { Character } \\
\text { Type }\end{array}$ & Antagonist & Character Type \\
\hline Seethaswayamvaram & SREERAMA & Pacha & PARASURAMA & Minukku \\
\hline Baalivadham & SREERAMA & Pacha & BAALI & Chuvanna Thaadi \\
\hline Bakavadham & BHEEMA & Pacha & BAKA & Chuvanna Thaadi \\
\hline Kalyanasaugandhikam & BHEEMA & Pacha & KRODHAVASAN & Chuvanna Thaadi \\
\hline Kaalakeyavadham & ARJUNA & Pacha & KAALAKEYA & Chuvanna Thaadi \\
\hline Kiratham & ARJUNA & Pacha & KATTALA & Kari \\
\hline Baalivijayam & RAVANA & Kathi & BAALI & Chuvanna Thaadi \\
\hline Keechakavadham & KEECHAKA & Kathi & BHEEMA & Minukku \\
\hline Dakshayagam & DAKSHA & Pacha & VEERABHADRA & Chuvanna Thaadi \\
\hline Nalacharitham & NALA & Pacha & KALI & Chuvanna Thaadi \\
\hline Duryodhanavadham & DURYODHANA & Kathi & BHEEMA & Pacha \\
\hline Raajasooyam & SISHUPALA & Kathi & BHEEMA & Pacha \\
\hline Narakasuravadham & NARAKASURA & Kathi & KRISHNA & Pacha \\
\hline Baanayudham & BAANA & Kathi & VISHNU & Pacha \\
\hline
\end{tabular}


Table II Kinesics of Protagonists and Antagonists (Kalasaams) in Kathakali

\begin{tabular}{|l|l|l|l|}
\hline Character Role & Kalama (name) & Thaala (Basic beats) & Tempo \\
\hline \multirow{2}{*}{$\begin{array}{l}\text { Pacha (Protagonists) } \\
\text { Kathi (Protagonists) }\end{array}$} & Adantha & $56,28,14$ & \multirow{3}{*}{ Slowest \& Medium } \\
\cline { 2 - 3 } & Chamba & 40,20 & \\
\cline { 2 - 3 } $\begin{array}{l}\text { Chuvanna } \\
\text { (Antagonists) }\end{array}$ & Chempata & $32,16, \& 32$ & \\
& Adantha & 14 & \multirow{4}{*}{ All Fast Tempos } \\
\cline { 2 - 3 } & Chambal & 10 & \\
\cline { 2 - 3 } & Chempata & 8 & \\
\cline { 2 - 3 } & Muriyadantha & $31 / 2$ & \\
\hline
\end{tabular}

Table III Grunts of Protagonists and Antagonists

\begin{tabular}{|l|l|}
\hline Character Type & Grunt pronunciation \\
\hline Pacha \& Minukku & No Grunts \\
\hline Kathi & Gwagooiiii..... \\
\hline $\begin{array}{l}\text { Thaadi- Chuvanna } \\
\text { Thaadi }\end{array}$ & Ghooooooo..... \\
\hline $\begin{array}{l}\text { Thaadi- } \\
\text { Thaadi }\end{array}$ & Pella \\
\hline Kari (male) & Pooppuuu...... . Phooya..... \\
\hline Kari (female) & Keeeee...... \\
\hline
\end{tabular}

Table IV Character Types used to study non-verbal communication of Protagonists and Antagonists

\begin{tabular}{|l|l|l|l|l|}
\hline Story & Protagonist & $\begin{array}{l}\text { Character } \\
\text { Type }\end{array}$ & Antagonist & Character Type \\
\hline Baalivadham & SREERAMA & Pacha & BAALI & Chuvanna Thaadi \\
\hline Bakavadham & BHEEMA & Pacha & BAKA & Chuvanna Thaadi \\
\hline Dakshayagam & DAKSHA & Pacha & VEERABHADRA & Chuvanna Thaadi \\
\hline Nalacharitham & NALA & Pacha & KALI & Chuvanna Thaadi \\
\hline
\end{tabular}




\section{Summary and Conclusions}

The following facts can be drawn from the analyzed data. Kathakali makes use of all areas of nonverbal communication very effectively. This art form has its own built-in intricacies techniques to handle communication. The depicted Bhava when communicated via three aspects of Chadurvidhabhinaya gets transformed as Rasa in the minds of connoisseurs. The major transfer is via non-verbal means. Thus Kathakali's methods of non-verbal communication are both unique and effective.

In Kathakali all major forms of non-verbal communication viz. Kinesics, Gait, Postures \& Gestures, Grunts, Oculesics work in unison. Each one compliments the others. During body movements i.e. Kinesics, the actor starts from a definite Posture, executes a fixed pattern of steps Gait and Gestures with Mudras on hands, apt eye positioning -Oculesics and ends in a predefined final Posture. Appropriate Grunts are uttered during this process. Thus all aspects of nonverbalism are performed simultaneously. This is achieved by long and rigorous training process. The faculties are first trained individually and later tuned together. Thus an actor first gets trained in leg movements, and then learns Mudras of hands with static posture. The training in Oculesics, Kannusadhakam and Bhavabhinaya -facial expression is learned separately. During the second stage of training of Cholliyattam all these aspects are integrated. Thus the audio-visual and kinesthetic faculties are synchronized and embedded in the final process of Enacting.

Thus the roles of Kinesics, Gait, Haptics, Postures, Gestures, Grunts, and Oculesics are very important and are totally synchronized in Kathakali performance by continuous training. All these complementing elements work together in enacting. It is difficult to judge which plays important role. In the depiction of Bhava-Emotion, Oculesics play important role. However, the unique language and the embedded system of Kinesics where more elements work together may be considered as a prime factor in the totality of process of non-verbal communication in Kathakali.

Kathakali characters are classified as types, depending upon, mostly the emotional and social state at the time of Scene or Story. Unlike our Epics, the Protagonists in Kathakali may not be righteous or divine. Protagonists resemble heroes of Shakespearian Tragedies and are men of self-achievement. The Protagonists of stories of earlier origin are righteous Pacha type. Very generally speaking, Pacha or Kathi types are Protagonists and dynamic, quick-acting, vigorous Chuvanna Thaadi who protests are mostly Antagonists. In addition to the appearance, these character roles differ in the tempo of non-verbal communication. The bit-rate transfer of Antagonists is very high as they are in furious excited state. But surely, there exist many similarities between Protagonists and Antagonists.

This indigenous theatre of Kerala has many intricate methodology of in-built non-verbal communication. An in-depth study of the classical elements of this theatre will surely throw light upon these otherwise obscure elements and might help to explore new realms for modern means of non-verbal communication. 


\section{References}

Menon, Achuthankutty, I, “ A Hand Book Of Kathakali “, Janabheri (2013)

Narayana Pisharadi, K.P, “Natyashastram (translation)”, D.C Books (1993)

Menon, Achuthankutty,I, “Kathakalippadangal (Verses of Kathakali)”, Thiranottam (2010)

Warrier, Rama, “ Kottayathu Thamburantae Atta Kathakal”, D.C Books (1976)

Ayyar,Ullur,S,Parameshwaran, “ Kerala Sahithya Charithram”, History of Kerala literature (1990)

Unnikrishnan,C.P, “ A Window to kathakali”, (2000)

Zarrilli, Philip, “Kathakali dance drama: where Gods and Demons come to Play”, (1999)

Bolland, David, “The Ramayana in Kathakali Dance Drama”, ( 2006)

University, R. T. (2010). Indian Aesthetics. Rajasthan: Raj Technology University.

Center, N. C. (2003). The Mahabharatha story and Kathakali. Culcutta, India: Nataraj Culture Center.

Freundfor, D. (2013). Nonverbal social sensing. 05-06.

kent, A. (2013). Hand gestures inKimmeravadham. 04-o6.

Zarilli, P. (2000). Kathakali dance drama where gods and demons come to play. London: Routledge.

Vishnu Achutha Menon is a Ph.D. scholar and Boobalakrishnan N is a faculty at the department of media and communication, Central University of Tamil Nadu. 